\title{
Local Wisdom Anti-Hoax Values in Sundanese Proverb A Semiotic Approach
}

\author{
Aan Ramadhansyah Rahayu \\ Faculty of Cultural Science, Universitas Padjadjaran \\ Bandung, Indonesia \\ E-mail: arrahayu13@gmail.com
}

\begin{abstract}
This study analyzed the wisdom values contained in Sundanese proverb that relates to anti-hoax values. This study was conducted to bring back character and philosophy of Sundanese community which contained in the Sundanese proverb, in order not to be forgotten and still applied in everyday life. The source of the data that collected in this study is derived from Babasan and Pribahasa Sunda Book. The method used in this study is a qualitative method with semiotic analysis approach of Roland Barthes. The purpose of this study is to analyze and describe anti-hoax values that contain in Sundanese proverb. The result shows that the proverb of Sundanese contains anti-hoax values. Those values are values of accuracy in reading Information and values of honesty.
\end{abstract}

Key words: local wisdom, anti-hoax values, proverb Sundanese, semiotic, Roland Barthes

\section{INTRODUCTION}

Sundanese society is a tribe who live in West Java, and this tribe is claimed as the majority tribe who live in this region. This tribe use Basa Sunda as a tool of communication, and they also use national language (bahasa Indonesia) when they interact with people from other regions. Since the development era, West Java become the most wanted region that people from other regions are willing to live and stay in Bandung (capital city of West Java). As a result, West Java become a region that experiences multicultural and acculturation of culture which effect to the originity of Sundanese culture. Acoording to Edward B Tylor (1871) as cited in Danesi \& Peron (1999), define culture as a complex whole including knowledge, belief, art, morals, law, custom, and any other capability or habit acquired by human beings as members of society. Therefore, Sundanese society as the largest tribe in West Java might have vary in their culture since the acculturation of knowledge, belief, moral and custom with other tribes. Thus, Sundanese society as native people who live in West Java need to preserve their old cultural values so that their identity is still exist. 
The identity of Sundanese society is shown in numerous moral values and old saying (proverb) in the form of Sundanese culture. This culture have enriched the local wisdom that add the values as local identity. Local Wisdom is a combination of knowledge and traditions that are specific to a certain region, and that are passed on from generation to generation. Therefore local wisdom play a role as a local identity and also encourages a sense of pride in culture and proud of the region as it contributes to the development of national culture (Nasrudin, 2010:265). The contribution can be in form of preserving and practising the local proverbs which contain values of life.

Indeed, Sundanese society is rich of proverb or old saying that indicates the philosophy of Sundanese people's life. Some researches have been conducted in term of local wisdom and Sundanese proverb. First, research about local wisdom in Sundanese proverb, this research attempts to classified Sundanese proverbs according to their values (S. Kodariah \& G. Gunardi, 2015). Second, research about Sundanese proverbs as local wisdom, this research classify kinds of proverbs and kinds of local wisdom (Wagiati \& Sugeng Riyanto, 2015). Third, research about values of local wisdom of Sundanese proverb, which describe Sundanese proverbs that rule human relation with God, and human relation with nature (Hendri Sugara, 2016). Fourth, research about harmony values in Sundanese proverb, this research analyze and describe some Sundanese proverbs that contain harmony values in life (Susi Yuliawati, 2018).

Meanwhile, this study concerns on local wisdom Sundanese proverb relates to antihoax values. The reason why the writer chooses this title is due to the research conducted by LIPI (2018) stated that West Java is the second region which produces hoax higher than other regions. The uncontroll of hoax production is seen as an effect of digital era, where in this era, information is easy to be accessed, easy to be spread (just one click), and people are easy to get fooled, they seem could not differentiate which information is real and which one is fake. By conducting this study, hopefully Sundanese society can be reminded again the philosophy of life that contains in Sundanese proverb related to antihoax values which has been passed on from generation to generation. Moreover, the writer believes that it is important to identify and redefine our identity by using our local wisdom to cope with the challenging global influence and to give contribution to the world. Thus, this study covers two research questions: (1) What are anti-hoax values contain in Sundanese proverb? (2) What are the meaning of Sundanese proverbs that 
contain anti-hoax values? Hopefully, this study could reveal they way how our ancestor deal with hoax and how to avoid it.

\section{LITERATURE REVIEW}

\section{Local Wisdom}

Lexically, the word local wisdom consists of the word local and wisdom. According to Oxford Dictionary, local (adj) means relating or restricted to particular area. Wisdom (n) means the quality of having experience, knowledge, and good judgment; the quality of being wise. Based on the dictionary meaning, local wisdom refers to experience, knowledge, and the quality of being wise in particular area. 'Being wise', according to Rahyono (2009) indicates that he/she has a good personality because he/she is able to create a situation that makes other people feel being appreciated. 'Being wise' means that he/she is able to cope with problems by using his/her intelligence. Therefore 'being wise' is a result of human intelligence that can be utilized by others as intelligence facilities.

In addition, the term 'local wisdom' used to be associated with term 'local genius', according to Wales (cited in Rahyono, 2009) local genius is defined as a set of cultural characteristics that owned by the society as a result of early life experiences. Yuliawati (2018) argues this idea indicates local genious is regarded as human intelligence obtained by a group of people through 'making meaning activity' toward the events that happend in life. Therefore, this intelligence, that is in the form of mutual understanding then becomes part of cultural character possessed by society.

Local wisdom can be interpreted as a form of intelligence that is owned by a group of society based on its experience. Therefore, local wisdom is a kind of share knowledge that become characteristic of a certain culture to guide people in society to act and to behave (Yuliawati, 2018). Moreover, Rahyono (2009) also explained that a nation's personality is depend on how strong is the local wisdom. If the power of local wisdom has faded away, then the nation's personality will fade away because local wisdom is a part of characteristic of nation.

\section{Semiotic}

The term semiotic comes from Greek word semeion, means sign or symptom. Semiotics is a study about how meanings are made and how reality is represented, the 
goal of this study is to investigate the implicit meaning of the messages. The meaning itself can be found in the form of sign. The two main founders of semiotics are Saussure and Pierce. Saussure (a stucturalism linguist) uses the term semiology and argues that signs consist of binary system (signifier and signify) while Pierce (a philosopher) uses the term semiotic, argues that signs has triadic system (representamen, object, interpretant). No matter what view the signs are taken, the general objective of theoritical semiotics is to explain how signs allow human being to know. Danesi (1999) states that the meanings of signs are the data that semioticians collect, and meanings are what they try to understand.

Barthes applied the concept of semiology Ferdinand Saussure, he argues that a text need to be constructed if we want to find out its meaning (what is beyond the sign), furthermore he developed this concept into a method to analyze the culture. It began when Barthes frequently interrogated specific culture materials in his collection, Mythologies (1957) in order to expose how bourgeois society asserted its value through them, for example the text: drink wine and be French. To drink wine is to be part of France, is to be French; it forces people to have a certain view regarding wine and France. This is how myths function in modern society (according to Barthes). Myth takes a purely cultural and historical object such as wine and alter it into the sign of a universal value: a collective French identity. In fact, the portrayal of wine in French society as a strong and healthy habits is a bourgeois ideology that is contradicted by exact realities. Mythology changes one culture's values, in Barthes's case bourgeois French culture, into a universal value: it turns culture into nature, often while still recognizing its status as myth, as a cultural product.

Barthes sees sign as a system that consists of expression $(\mathrm{E})$, in relation $(\mathrm{R})$ to content (C). this system is symbolized as $\mathrm{E}-\mathrm{R}-\mathrm{C}$. Barthes also argued that meaning is not statis but dynamic. Therefore, he introduced the concept of doubleness in meaning, that meaning consists in two level, they are primary system, or it is called as denotative meaning, formulated as $\mathrm{E}_{1}-\mathrm{R}_{1}-\mathrm{C}_{1}$ and secondary system, or it is called as connotative meaning, formulated as $\mathrm{E}_{2}-\mathrm{R}_{2}-\mathrm{C}_{2 . .}$ In the secondary meaning, the meaning can be expanded to expression $\left(\mathrm{E}_{2}\right)$ or content $\left(\mathrm{C}_{2}\right)$. 
In the secondary meaning, if the expression (E) is expanded, it results synonymy to refer to the same content (picture 1). For example, the synonymy of jail in bahasa Indonesia are hotel prodeo; lapas; bui. This process is known as metalanguage. If the content $(\mathrm{C})$ is expanded, it results new meaning to refer to the same expression. For example jail which means a place for sinners, may have another meaning such as a place to change bad people to become good people. This process is known as connotation (picture 2)

\section{Picture 1: Model of Barthes Metalanguage}

\begin{tabular}{|c|c|c|}
\hline \multirow[b]{2}{*}{$\begin{array}{l}\text { Secondary } \\
\text { system }\end{array}$} & \multicolumn{2}{|c|}{ Metalanguage } \\
\hline & & ${ }_{2} C_{2}$ \\
\hline $\begin{array}{l}\text { Primary } \\
\text { system }\end{array}$ & Denotation & $\begin{array}{lll}\mathrm{E}^{1} & \mathrm{R}^{1} & \mathrm{C}^{1}\end{array}$ \\
\hline
\end{tabular}

Picture 2: Model of Barthes Connotation

\begin{tabular}{|c|c|c|}
\hline \multirow[b]{2}{*}{$\begin{array}{l}\text { Secondary } \\
\text { system }\end{array}$} & \multicolumn{2}{|c|}{ Connotation } \\
\hline & $E_{2}$ & $\$_{2} \quad C_{2}$ \\
\hline $\begin{array}{l}\text { Primary } \\
\text { system }\end{array}$ & $\begin{array}{lll}\mathrm{E}_{1} & \mathrm{R}_{1} & \mathrm{C}_{1}\end{array}$ & Denotation \\
\hline
\end{tabular}

Through secondary meaning that expanded content $(\mathrm{C})$ or connotation, Barthes criticized society that everything which seemed reasonable in a culture, in fact it is a process of connotation. If the connotation become stable, then it turns to be a myth (message), and if the myth become stable, it turns to be an ideology (Yuliawati, 2018)

\section{Sundanese Proverb}

According to Satjadibarata (1945) as cited in Rosidi (2005:5), proverb (paribasa) is compilation of words which are arranged into speech expression that contain meaning of life experience or become advice. In addition from a linguistic perspective, Prawirasumantri (1973:39) explained that proverb is a kind of comparison that has 
become a symbol of action in forming an expression. Moreover, Sudarajat stated (2003:99) proverb is an expression in form of sentences, usually it means the comparison or 'siloka' of human life action.

To differentiate between sentence and proverb, Tamsyah (1994: 9 - 10) explained the characteristic of proverbs, they are:

1. proverb has characteristic to compare or to personify;

2. proverb is an expression which has not real meaning;

3. proverb is a clause that close to the hearth of someone who expressed it.

4. proverb could not be changed as it has become 'pakeman'

Gandasudirja (1977:80) explained that proverb is an expression that has a fixed arrangement and consists of human life experience, it become an advice that has been stated by the ancestor.

Based on some definiton above, it is concluded that proverb is language expression in from of sentence which has not real meaning. Proverb contain some advice, and it is owned by a particular society based on the cultural values that passed from generation to generation and used as fondation for the society member to act and to behave.

\section{METHODOLOGY}

Based on the research questions above, this study applied descriptive qualitative method research. Qualitative research is a research which has purposed to describe and to analyze phenomenon, events, social activity, belief, perception, and individual or group thought (Moleong, 2007:7). The descriptive qualitatif method in this study is adapted with the theory of Roland Barthes semiotic model (1915-1980)

The data is taken from Pribahasa and Babasan Sunda (Rosidi, 2011). The writer read and look for the Sundanese proverbs which contain anti-hoax values in their meaning. After all the data gathered, the analysis is done to interpret values that contain in the data. The values of Sundanese proverb are analyzed based on Roland Barthes semiotic theory, first analyzing the denotative meaning, second analyzing the connotative 
meaning. Therefore, drawing conclusion based on the data interpretation to answer the reserach questions.

\section{RESULTS AND DISCUSSION}

As this research attempts to reveal Sundanese local wisdom through Sundanese proverbs, specifically those proverb which contain anti-hoax values. This research try to analyze and describe five Sundanese proverb that contain anti-hoax values.

\section{Values of Accuracy in Reading Information}

\section{(1) Bobot pangayun timbang taraju}

Legs are heavier than shoulder

The proverb, semiotically is a sign in a form of sentence (language) that need to be interpreted. This sign consists of one clause and it is a kind of declarative sentence. According to Sundanese dictionary (kamus-sunda.com) the word 'bobot' means 'heavy', 'pangayun' means 'step', 'timbang' means 'than' and 'taraju' means shoulder.

This proverb has denotative meaning that to move the legs is heavier than to move the shoulder. Legs are the bottom part of human body that hold the weight of body, thus it is heavier to move the legs than shoulder which is the upper part of body do not hold the weight of body. Therefore, we need to be careful when we move the legs as it hold the weight of body.

This proverb has connotative meaning that we must think first before we act. That every single step needs to be done carefully. This connotative meaning tell us to think first before you click the button 'share' in social media. Think about what will happen next after sending the information, whether it is useful or useless, whether it is beneficial or detrimental to others.

The meaning of this proverb reflects the local wisdom of Sundanese society that carefulness is something must be considered. Moreover, in this digital era, the carefulness in reading and checking information is a must since a lot of information in cybership is easy to be accessed, but those information must be filtered first to ensure that the information is not a hoax. 


\section{(2) Nyaur kudu diukur nyabda kudu di unggang}

Calling must be measured, saying must be gradually

This sentence consists of two clauses and syntactically has the same pattern: gerund - verb - adjective, and it is a kind of imperative sentence as the subject is ellipsed. According to Sundanese dictionary (kamus-sunda.com) the word 'nyaur' means 'to call', 'kudu means 'must', 'diukur' means 'measured, 'nyabda' means to say, 'diunggang' means 'gradually'.

This proverb has literal meaning, if we call someone we must be able to predict whether our voice is clearly heard or not, also when we talk or say about something must be slowly or gradually, not talking too fast so that other people would understand what we said.

This proverb has connotative meaning, if we speak about something, we must speak clearly and meaningfully. If we do not speak clearly, others would not understand our message, and if we speak meaningless, others would not listen to us. In this digital era, we must be able to read carefully about information that shared in social media, and try to understand the meaning of the information. By doing this, we would not be easy to share the information that we do not know the truth. Sharing information which the truth is daubtful is same as sharing hoax to the world. Meanwhile, Sundanese ancestors have kept this proverb as local wisdom to avoid hoax among Sundanese society.

\section{(3) Ulah ngukur baju sasereg awak.}

Don't measure clothes as narrow as the body

This sign consists of one clause, the clause begins with the word 'don't' it indicates that it is an imperative sentence. According to Sundanese dictionary (kamus-sunda.com) the word 'ulah' means 'do not', 'ngukur' means 'measure', 'baju' means 'clothes', 'sasereg' means 'narrow', and 'awak' means 'body'.

This proverb has denotative meaning that if you are making clothes, you are not supposed to measure your clothes as tight as your body as it may cause uncomfortable to your body, or the clothes your wear might be torn when you move actively. Thus, this sentence literally give prohibition to wear clothes that as narrow as the body since it may cause uncomfortable to the body, hurt the body, or even tear up the clothes. 
The connotative meaning of the proverb is that we need to see things objectively, not only in one side. Neither in the side of clothes, nor in the side of body. In relation to digital era, this proverb gives prohibition to see and read information only in one source, we need to compare it with other sources. Thus we could believe that we have right information before we share it to others. If we only seeing information or problem in one side, the others could be in problem, fell uncomfortable, or even broke good relationship.

Definitely, the connotative meaning of this proverb reflects the local wisdom of Sundanese society which has been passed from generation to generation, it reflects Sundanese ancestors believe that being objective in seeing problem wiould avoid us in having problem with others.

\section{Values of Honesty}

\section{(4) Kalakuan ngaliarkeun taleus ateul}

The behavior of spreading itchy taro

This sentence consists of one clause and categorized as declarative sentence. According to Sundanese dictionary (kamus-sunda.com) the word 'kalakuan' means 'behavior', 'ngaliarkeun' means 'spread', 'taleus' means 'taro', and 'ateul' means 'itchy'. Sudanese proverb is familiar with the word 'taleus' (taro), a lot of Sundanese proverb mention it, and this proverb is one of them. 'Taleus' is a kind of tubers which contains itchy substances, sometimes it gives itchy to our tounge when we eat it too much, or if we touch its sap. Literally, this proverb has meaning do not spread taro carelessly, its sap contains itchy substances and make you feel itchy. Once you've got itchy, you want to scratch it, and it might leave scars.

Connotatively, this proverb tells if we find out that news / information is untrue we must not spread that information. In other words, we must not share hoax. Once the hoax spreading, it may leave scars to others who feel aggrieved. In fact, this proverb show local wisdom of how Sundanese society had experienced things like hoax long times ago, and this proverb appears to provide social rule in facing hoax. Therefore, this proverb is very meaningful in this digital era, to remind Sundanese society not to carelessly share information that contain hoax.

\section{(5) Nu sejen kudu dilainkeun, nu enya kudu dienyakeun}




\section{The other must be other, the right thing must be justified}

This sentence consists of two clauses, and it is a kind of imperative sentence as the subject is ellipsed. According to Sundanese dictionary (kamus-sunda.com) the word ' $\mathrm{Nu}$ sejen' means 'others', 'kudu means 'must', 'dilainkeun' means 'other, 'nu enya' means 'the right thing', 'dienyakeun' means 'justified'. Literally, this proverb tells us to say yes if it is yes, and say no if it is not. This denotative meaning could expand its meaning, and create connotative meaning, that is: we must tell the truth, and we must not tell lies. This myth (message) has been established among Sundanese ancestor, it indicates that Sundanese society uphold honesty values even since the old times. Now, in digital era, the attitude of being honest is highly demanded as people are easily create and share fake news. In relation to hoax, this proverb remind us again about being honest when we write information, and being honest if what we had carelessly shared fake news. This local wisdom could avoid Sundanese society to become hoax community, conversely it turns back Sundanese society to uphold the values of honesty, and fight back hoax in society and importantly fight back hoax in cyberspace.

\section{CONCLUSION}

The description above concludes that Sundanese society has cultural values that could block them from spreading and creating hoax. These cultural values are regarding on the accuracy in reading information and the attitude of being honest. Actually, Sundanese ancestor had created myth about being accurate in reading information and being honest in social interaction, these myths are given in the form of verbal sign as proverb. These myths were created to teach or to approve the concept of anti-hoax values. Semiotically, we also could interpret that in Sundanese's life philosophy the values of being careful in reading information and be honest are particularly important to increase awareness in fighting hoaxes. Therefore, Sundanese society must be able to preserve these myths to be able to fight hoaxes, especially in West Java. Eventhough, West Java society is multicultural, Sundanese is still as a majority, Sundanese society could influence other societies, or play role in transmitting anti-hoax values by applying these mythes in everyday life, in order to decrease hoaxes in West Java. 


\section{REFERENCES}

Prawirasumantri, A. e. (1973). Idiomatik Sunda. Bandung: FKKS.

Barthes, R. (1977). Element of Semilology. New York: Hill and Wang.

Chandler, D. (2002). Semiotics: The Basics. London: Routledge.

Fairclough, N. (2003). Analyzing Discourse: textual Analysis for Social Research. London: Longman.

Gandasudirdja, R. M. (1977). 700 Paribasa Sunda. Bandung: Firma Ekonomi.

Graham, A. (2000). Intertextuality (The New Critical Idiom). London: Routlege.

Marcel Danesi, Paul Perron. (1999). Analyzing Cultures: An Introduction and Handbook. Indiana: Indiana University Press.

Moleong, L. J. (2007). Metodologi Penelitian Kualitatif. Bandung: PT Remaja Rosada Karya.

Nasrudin. (2010). Kearifan Lokal dalam Pappaseng Bugis. Jurnal Sawerigading, Vol 16 No. 2.

Prawirasumantri, A. e. (1973). Idiomatik Sunda. Bandung: FKKS.

Rahyono, F. .. (2011). Kearifan Budaya dalam Kata. Bandung: Kiblat Utama.

Rohaedi, A. (1986). Kepribadian Budaya Bangsa (Local Genius). Jakarta: Pustaka Pelajar.

Rosidi, A. (2011). Babasan \& Paribasa. Bandung: Kiblat Utama.

Siti Kodariah, Gugun Gunardi. (2015). Nilai Kearifan Lokal dalam Peribahasa Sunda, Kajian Semiotika. Patanjala, Vol . 7 No. 1.

Sudrajat. (2003). Elmuning Basa. Bandung: Wahana Luang.

Sugara, H. (2016). Values of Local Wisdom of Sundanese Proverb. Journal of Indonesia Language Education and Literary, Vol 1, No. 2.

Tamsyah, B. R. (1994). 1000 Babasan jeung Paribasa. Bandung: Pustaka Setia.

Wagiati, Sugeng Riyanto. (2015). Peribahasa Sunda sebagai Sumber Kearifal Lokal. International Conference on Language, Culture, and Society. Jakarta: Lembaga Ilmu Pengetahuan Indonesia.

Yuliawati, S. (2018). Nilai-Nilai Kerukunan Dalam Pepatah Sunda: Kajian Semiotik Tentang Kearifan Lokal. In D. Reiza Diena Putra, Menjejaki Integritas Social Budaya (pp. 43 - 62). Bandung: Balatin Pratama. 